\title{
PENGENDALIAN KUALITAS AIR PADA PERUSAHAAN DAERAH AIR MINUM TIRTA MEULABOH UNTUK MENINGKATKAN LAYANAN KEPADA MASYARAKAT
}

\author{
Fitriadi $^{1)}$ \\ ${ }^{1)}$ Dosen Program Studi Teknik Industri Fakultas Teknik Universitas Teuku Umar \\ fitriadi@utu.ac.id
}

\begin{abstract}
Water is a basic need that is very important for humans and other living creatures. Drinking water is water whose quality meets health requirements and can drink, it was clean water is water used for daily necessities whose quality meets the requirements of health and can be taken if it has been cooked. The quality of products is one of the most important factors affecting the company's progress, as well as for the water company. In this regard discuss about water quality control if it meets quality standards or not. Quality Control of water in accordance with the standardization and quality standards are allowed very closely related to the level of customer satisfaction. Control of the quality of a product can be done by measuring the different variables that influence it. One way to measure and determine the quality of a product is by using the Taguchi method is done with the design parameters is one of the design phase of a product or process. So hopefully by doing this study water quality PDAM Tirta Meulaboh can be controlled and can be controlled which can certainly improve water services to the people of Aceh Barat.
\end{abstract}

Kata Kunci : Water, Quality Control, Customer Satisfaction, Taguchi.

\section{PENDAHULUAN}

Air merupakan kebutuhan dasar yang sangat penting bagi manusia dan makhluk hidup lainnya. Air minum adalah air yang kualitasnya memenuhi syarat kesehatan dan dapat langsung diminum, sedang air bersih adalah air yang digunakan untuk keperluan sehari-hari yang kualitasnya memenuhi syarat-syarat kesehatan dan dapat diminum apabila telah dimasak.

Kebutuhan air bersih di kota Meulaboh dikelola oleh Perusahaan Daerah Air Minum (PDAM) Tirta Meulaboh dengan menggunakan 3 (tiga) Instalasi Pengolahan Air (IPA) yang terletak di Gampong Lapang, Beuregang dan Ranto Panjang. Instalasi Pengolahan Air (IPA) yang dibangun oleh PDAM Tirta Meulaboh merupakan perwujudan dari upaya peningkatan kualitas air bersih. Perusahaan Daerah Air Minum Tirta Meulaboh dituntut untuk bisa menyediakan pasokan air bersih untuk masyarakat Meulaboh dan sekitarnya secara konstan dan terus menerus.

Kualitas produk merupakan salah satu faktor terpenting yang mempengaruhi kemajuan perusahaan, demikian juga halnya untuk perusahaan air bersih. Dalam hal ini 
dibahas mengenai pengendalian kualitas air apakah memenuhi standar mutu atau tidak. Pengendalian kualitas air sesuai dengan standarisasi dan baku mutu yang diizinkan sangat erat sekali hubungannya dengan tingkat kepuasan pelanggan.

Perusahaan yang menghasilkan produk dan jasa yang lebih berkualitas memiliki peluang yang lebih besar untuk memenangkan persaingan sekaligus meraih keuntungan maksimal. Hal inilah yang mendorong produsen dalam bidang manufaktur dan jasa untuk memperhatikan masalah kualitas produknya (Montgomery, 2001). Peningkatan atau perbaikan mutu dapat dicapai salah satunya dengan pengendalian kualitas yang tepat. Terdapat dua pendekatan yang dapat digunakan dalam pengendalian kualitas, yaitu On-line Quality Control dan Off-line Quality Control. Salah satu metode pengendalian kualitas secara Off-line Quality Control adalah metode yang diusulkan oleh Dr. Genichi Taguchi (1940), yang dikenal dengan metode Taguchi. Dalam metode Taguchi digunakan matrik yang disebut Orthogonal Array (OA) untuk menentukan jumlah eksperimen minimal yang dapat memberi informasi sebanyak mungkin semua faktor yang mempengaruhi parameter. Bagian terpenting dari orthogonal array terletak pada pemilihan kombinasi level dari variabel-variabel input untuk masing-masing eksperimen.

Metode Taguchi merupakan suatu pendekatan terstruktur untuk menentukan kombinasi terbaik dalam menghasilkan produk berupa barang atau jasa, sehingga banyak perusahaan-perusahaan mengaplikasikan metode Taguchi dalam rangka memperbaiki kualitas produk dan proses. Perancangan parameter adalah suatu metode untuk meningkatkan kualitas dengan cara mengatur parameter produk atau proses sedemikian sehingga performansi produk menjadi tidak sensitif terhadap penyebab keragaman (Ross, 1996). Tujuan Penelitian adalah:

a. Mengidentifikasi masalah produksi dan faktor utama penyebab kegagalan (reject) dalam proses produksi air di PDAM.

b. Mengidentifikasi kecacatan yang terjadi dan faktor-faktor penyebab terjadinya kecacatan pada produk akhir.

c. Untuk menentukan batas toleransi terhadap kualitas produk yang dihasilkan.

d. Memperoleh desain eksperimen solusi dalam upaya mengendalikan kualitas air di PDAM dengan menggunakan metode Taguchi. 


\section{KAJIAN LITERATUR}

\subsection{Definisi Kualitas}

Menurut Juran M.J (2004), kualitas produk adalah kecocokan penggunaan produk (fitness for use) untuk memenuhi kebutuhan dan kepuasan pelanggan. Kecocokan penggunaan itu didasarkan atas lima ciri utama berikut:

a. Teknologi, yaitu kekuatan atau daya tahan

b. Psikologis, yaitu citra rasa atau status

c. Waktu, yaitu kehandalan

d. Kontraktual, yaitu adanya jaminan

e. Etika, yaitu sopan santun, ramah atau jujur

Menurut Crosby dalam Nasution (2004) Kualitas adalah conformance to requirement, yaitu sesuai dengan yang disyaratkan atau distandarkan. Suatu produk memiliki kualitas apabila sesuai dengan standar kualitas yang telah ditentukan. Standar kualitas meliputi bahan baku, proses produksi dan produk jadi.

Deming E dalam Yamit (2004) Kualitas adalah kesesuaian dengan kebutuhan pasar. Perusahaan harus benar-benar dapat memahami apa yang dibutuhkan konsumen atas suatu produk yang akan dihasilkan.

Garvin dan Davis dalam Nasution (2004) Kualitas adalah suatu kondisi dinamis yang berhubungan dengan produk, manusia/tenaga kerja, proses dan tugas, serta lingkungan yang memenuhi atau melebihi harapan pelanggan atau konsumen.

Nasution M.N (2004) menyimpulkan ada beberapa persamaan dalam definisi kualitas, yaitu dalam elemen-elemen sebagai berikut :

a. Kualitas mencakup usaha memenuhi atau melebihi harapan pelanggan

b. Kualitas mencakup produk, jasa manusia, proses, dan lingkungan.

\subsection{Dimensi Kualitas}

Menurut Garvin (1996), dimensi kualitas untuk industri manufaktur, yaitu:

a. Performance, yaitu kesesuaian produk dengan fungsi utama produk itu sendiri atau karakteristik operasi dari suatu produk.

b. Feature, yaitu ciri khas produk yang membedakan dari produk lain yang merupakan karakteristik pelengkap dan mampu menimbulkan kesan yang baik bagi pelanggan.

c. Reliability, yaitu kepercayaan pelanggan terhadap produk karena kehandalannya atau karena kemungkinan rusaknya rendah. 
d. Conformance, yaitu kesesuaian produk dengan syarat atau ukuran tertentu atau sejauh mana karakteristik desain dan operasi memenuhi standar yang telah ditetapkan.

e. Durability, yaitu tingkat keawetan produk atau lama umur produk.

f. Serviceability, yaitu kemudahan produk itu bila akan diperbaiki atau kemudahan memperoleh komponen produk tersebut.

Kualitas pada industri manufaktur selain menekankan pada produk yang dihasilkan, juga perlu diperhatikan kualitas pada proses produksi. Hal terbaik adalah apabila perhatian pada kualitas bukan pada produk akhir, melainkan proses produksinya atau produk yang masih ada dalam proses (work in process), sehingga bila diketahui ada cacat atau kesalahan masih dapat diperbaiki, sehingga tidak ada lagi pemborosan yang harus dibayar mahal karena produk tersebut harus dibuang atau dilakukan pengerjaan ulang (Ariani D.W, 1999).

\subsection{Pengendalian Kualitas}

Prawirosentono S (2004), pengendalian kualitas adalah kegiatan terpadu mulai dari pengendalian standar mutu bahan, standar proses produksi, barang setengah jadi, barang jadi, sampai standar pengiriman produk akhir ke konsumen, agar barang (jasa) yang dihasilkan sesuai dengan spesifikasi mutu yang direncanakan.

Kegiatan pengendalian kualitas merupakan bidang pekerjaan yang sangat luas dan kompleks karena semua variabel yang mempengaruhi kualitas harus diperhatikan. Menurut Prawirosentono S (2004), secara garis besarnya, pengendalian mutu dapat diklasifikasikan sebagai berikut:

a. Pengendalian mutu bahan baku.

b. Pengendalian dalam proses pengolahan (work in process).

c. Pengendalian mutu produk akhir.

\section{METODOLOGI}

\subsection{Tipe Penelitian}

Tipe penelitian tergolong ke dalam penelitian deskriptif analitik, yaitu jenis penelitian yang mendeskripsikan pemecahan terhadap masalah yang dihadapi. Dengan adanya penelitian ini, diharapkan dapat memberikan solusi yang tepat dalam memecahkan permasalahan yang sedang dihadapi. 


\subsection{Lokasi Penelitian}

Lokasi penelitian dilakukan di Perusahaan Daerah Air Minum (PDAM) Tirta Meulaboh Kabupaten Aceh Barat yang terletak di Kecamatan Johan Pahlawan Desa Drien Rampak.

\subsection{Metode Penelitian}

Proses pengambilan data yang dilakukan secara bertahap, tahap-tahap ini pada dasarnya sama dengan model pelaksanaan penelitian dan dapat digunakan sebagai kerangka utama yang kemudian dapat dikembangkan sesuai kebutuhan. Pada tugas akhir ini penulis menggunakan data di Instalasi Pengolahan Air (IPA) Lapang PDAM Tirta Meulaboh Kecamatan Johan Pahlawan Kabupaten Aceh Barat. Menggunakan data yang bersumber pada data laporan kualitas air bulanan selama dua bulan Data selama dua bulan dipandang cukup untuk digunakan dalam mengendalikan kualitas air pada Instalasi Pengolahan Air (IPA) Lapang PDAM Tirta Meulaboh.

Metode Taguchi menggunakan seperangkat matriks khusus yang disebut matriks ortogonal (Orthogonal Array). Flowchart pengendalian kualitas air menggunakan metode Taguchi, gambar 3.1 sebagai berikut:

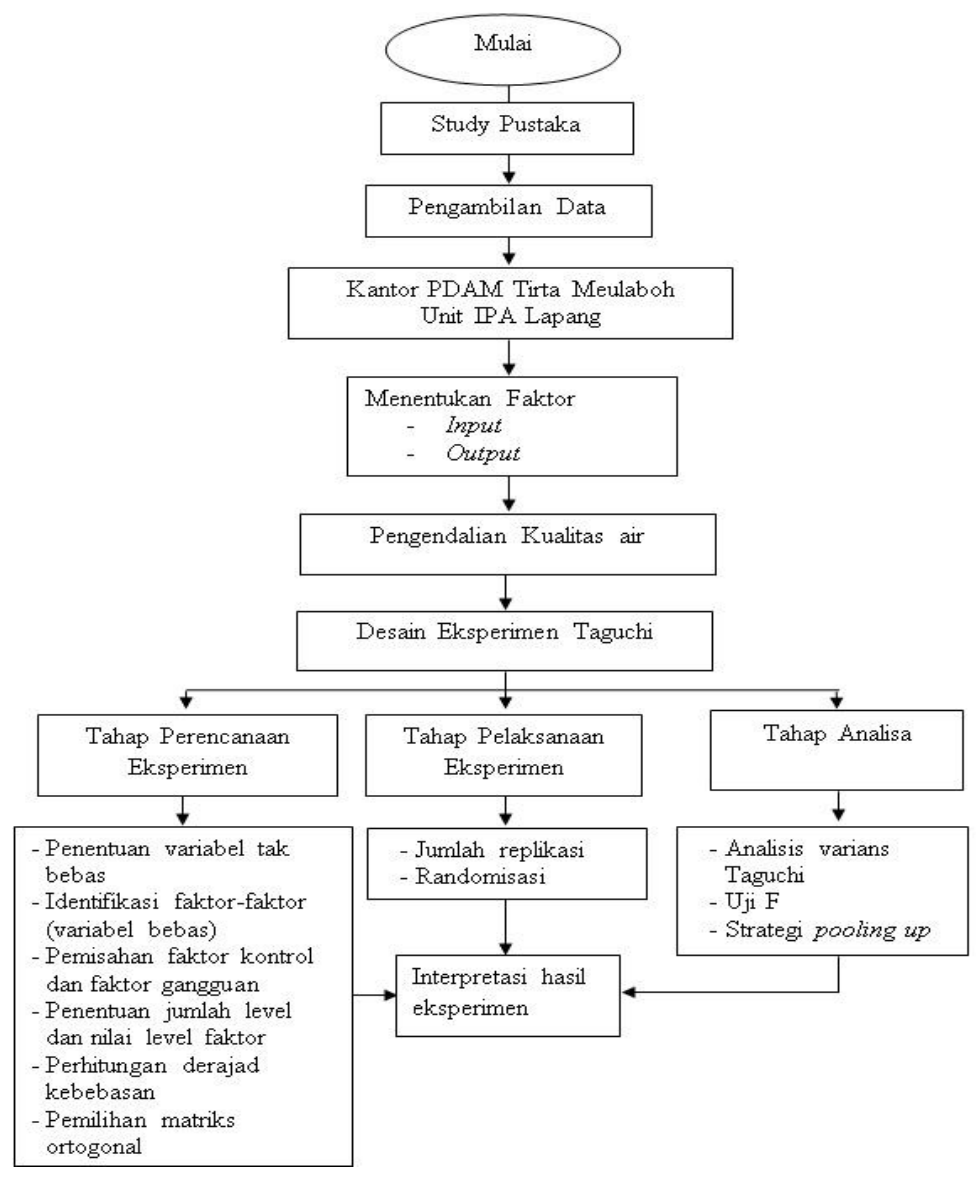

Gambar 3.1 Flowchart Metodologi Penelitian 
Matriks standar ini merupakan langkah untuk menentukan jumlah eksperimen minimal yang dapat memberikan informasi sebanyak mungkin semua faktor yang mempengaruhi parameter. Bagian terpenting dari metode matriks ortogonal terletak pada pemilihan kombinasi level variabel-variabel input masing-masing eksperimen.

\section{$\mathbf{L a}\left(\mathbf{b}^{\mathbf{c}}\right)$}

Di mana:

$\mathrm{L}=$ rancangan bujur sangkar latin

$\mathrm{a}=$ banyak baris/eksperimen

$\mathrm{b}=$ banyak level

$\mathrm{c}=$ banyak kolom/faktor

\section{HASIL DAN DISKUSI}

\subsection{Variabel Input}

Variabel input dalam penelitian ini adalah air baku dan jumlah tawas.

Tabel 4.1 Jumlah Air Baku pada Unit IPA Lapang PDAM Tirta Meulaboh

\begin{tabular}{cc}
\hline \multicolumn{2}{c}{ Jumlah Air Baku } \\
\hline Oktober $2014\left(\mathrm{~m}^{3}\right)$ & Nopember $2014\left(\mathrm{~m}^{3}\right)$ \\
$233.140 \mathrm{~m}^{3}$ & $171.170 \mathrm{~m}^{3}$ \\
\hline
\end{tabular}

Sumber: Data Sekunder unit IPA Lapang PDAM Tirta Meulaboh 2014

Sedangkan untuk jumlah tawas seperti yang terlihat pada tabel berikut

Tabel 4.2 Jumlah Tawas pada Unit IPA Lapang PDAM Tirta Meulaboh

\begin{tabular}{cc}
\hline \multicolumn{2}{c}{ Jumlah Tawas } \\
\hline Oktober $2014(\mathrm{~kg})$ & Nopember $2014(\mathrm{~kg})$ \\
6450 & 6650
\end{tabular}

Sumber: Data Sekunder unit IPA Lapang PDAM Tirta Meulaboh 2014.

\subsection{Variabel Output}

Variabel output dalam penelitian ini adalah Persyaratan Kualitas Air berdasatkan pada Permenkes RI Nomor 416/MENKES/PER/IX/1990 


\subsection{Hasil Pemeriksaan Kualitas Air.}

Hasil pemerikasaan kualitas air baku yang bersumber dari dari Sungai Meureubo, maupun kualitas air bersih hasil pengolahan PDAM Tirta Meulaboh unit IPA Lapang adalah sebagai berikut.

Tabel 4.3 Hasil Pemeriksaan Kualitas Air Baku Sungai Meureubo.

\begin{tabular}{|c|c|c|c|c|}
\hline No. & Parameter & Satuan & Persyaratan Maksimal & $\begin{array}{c}\text { Hasil Uji } \\
\text { Laboratorium }\end{array}$ \\
\hline & Fisika & & & \\
\hline 1. & Temperatur & ${ }^{0} \mathrm{C}$ & Suhu udara $(32) \pm 3$ & 29 \\
\hline 2. & Kekeruhan & NTU & 25 & 31 \\
\hline 3. & $\begin{array}{c}\text { Rasa dan Bau } \\
\text { Kimia }\end{array}$ & - & - & Tidak Berbau \\
\hline 1. & Salinitas & - & 0,1 & 0,1 \\
\hline 2. & $\begin{array}{c}\mathrm{pH} \\
\text { Bakteriologis }\end{array}$ & - & $6,5-9$ & 7,3 \\
\hline 1. & E.Coli & $\mathrm{Jlh} / 100 \mathrm{ml}$ & 0 & 0 \\
\hline
\end{tabular}

Hasil pemeriksaan air bersih dilakukan pada bulan Nopember 2014. Pengujian kualitas air bersih seperti yang terdapat pada tabel berikut.

Tabel 4.4. Hasil Pemeriksaan Kualitas Air Bersih

\begin{tabular}{|c|c|c|c|c|}
\hline No. & Parameter & Satuan & $\begin{array}{c}\text { Persyaratan } \\
\text { Maksimal } \\
\end{array}$ & $\begin{array}{c}\text { Hasil Uji } \\
\text { Laboratorium }\end{array}$ \\
\hline & Fisika & & & \\
\hline 1. & Temperatur & ${ }^{0} \mathrm{C}$ & Suhu udara $(31) \pm 3$ & 28 \\
\hline 2. & Kekeruhan & NTU & 5 & 4,9 \\
\hline \multirow[t]{3}{*}{3.} & Rasa dan Bau & - & - & Tidak Berbau \\
\hline & Kimia & & & \\
\hline & Tabel 4.4. Has & neriksaan $\mathrm{Ku}$ & litas Air Bersih (Lanju & an) \\
\hline No. & Parameter & Satuan & $\begin{array}{c}\text { Persyaratan } \\
\text { Maksimal }\end{array}$ & $\begin{array}{c}\text { Hasil Uji } \\
\text { Laboratorium }\end{array}$ \\
\hline 1. & Salinitas & - & 0,1 & 0,1 \\
\hline \multirow[t]{2}{*}{2.} & $\mathrm{pH}$ & - & $6,5-9$ & 7,2 \\
\hline & Bakteriologis & & & \\
\hline 1. & E.Coli & $\mathrm{Jlh} / 100 \mathrm{ml}$ & 0 & 0 \\
\hline
\end{tabular}

Sumber: PDAM Tirta Meulaboh Kabupaten Aceh Barat, Nopember 2014.

\subsection{Perencanaan Eksperimen dengan Metode Taguchi}

\subsubsection{Penentuan Variabel Tak Bebas}

Variabel tak bebas adalah kualitas air. Berdasarkan variabel tak bebas yang digunakan maka karakteristik yang digunakan yaitu smaller the better yang berarti bahwa berkurangnya jumlah produk yang cacat maka akan semakin baik kualitasnya. 


\subsubsection{Penentuan Variabel Bebas}

Variabel Bebas pada penelitian ini adalah faktor yang sangat mempengaruhi kualitas air yang mengakibatkan produk tersebut cacat. Adapun faktor-faktor tersebut adalah:

a. Air Baku (Air Sungai).

b. Pembubuhan Aluminium Sulfhate (Tawas).

c. Pengadukan Cepat.

d. Lama Waktu Pengadukan Cepat.

e. Pengadukan Lambat.

f. Lama Waktu Pengadukan Lambat.

g. Pengendapan/Sedimentasi.

\subsubsection{Penentuan Jumlah Level dan Nilai Level Faktor}

Penetapan level ini dapat dilihat pada tabel berikut ini.

Tabel 4.5. Penentuan Jumlah Level dan Nilai Level Faktor

\begin{tabular}{|c|c|c|c|c|}
\hline Kode & Faktor & Level 1 & Level 2 & Satuan \\
\hline $\mathrm{A}$ & Air Baku (Air Sungai) & Keruh & Agak Keruh & - \\
\hline B & $\begin{array}{l}\text { Pembubuhan Aluminium } \\
\text { Sulfate (Tawas) }\end{array}$ & $1,0-2,5$ & $1,0-2,5$ & Ppm \\
\hline $\mathrm{C}$ & Pengadukan Cepat & 100 & 110 & Rpm \\
\hline $\mathrm{D}$ & $\begin{array}{c}\text { Lama Waktu Pengadukan } \\
\text { Cepat }\end{array}$ & 60 & 70 & Detik \\
\hline $\mathrm{E}$ & Pengadukan Lambat & 30 & 40 & $\mathrm{Rpm}$ \\
\hline $\mathrm{F}$ & $\begin{array}{c}\text { Lama Waktu Pengadukan } \\
\text { Lambat }\end{array}$ & 15 & 20 & Menit \\
\hline $\mathrm{G}$ & Pengendapan/Sedimentasi & 20 & 30 & Menit \\
\hline
\end{tabular}

\subsubsection{Perhitungan Derajad Kebebasan}

Berdasakan hasil perhitungan didapat derajad kebebasan masing-masing faktor adalah 1 derajad kebebasan sehingga karena ada 7 faktor maka total seluruh derajad kebebasan adalh sebanyak 7 derajad kebebasan.

\subsubsection{Pemilihan Matriks Orthogonal (Orthogonal Array)}

Jumlah derajad kebebasannya adalah 7 banyaknya level $b=2$ level sehingga matriks orthogonal yang digunakan adalah $\mathrm{L}_{8}\left(2^{7}\right)$ di mana banyaknya eksperimen a $=8$ eksperimen.

4.4.6. Penempatan Kolom untuk Faktor dan Interaksi ke dalam Matriks Ortogonal. 
Penempatan kolom untuk Faktor dan Interaksi ke dalam Matriks Ortogonal seperti yang tercantum pada tabel berikut.

Tabel 4.6. Penempatan Faktor pada Orthogonal Array

\begin{tabular}{lc}
\hline \multicolumn{1}{c}{ Faktor } & Kolom \\
\hline Air Baku (Air Sungai) (A) & 1 \\
Pembubuhan Aluminium Sulfate (Tawas) (B) & 2 \\
Pengadukan Cepat (C) & 3 \\
Lama Waktu Pengadukan Cepat (D) & 4 \\
Pengadukan Lambat (E) & 5 \\
Lama Waktu Pengadukan Lambat (F) & 6 \\
Pengendapan/Sedimentasi & 7 \\
\hline
\end{tabular}

\subsubsection{Pelaksanaan Eksperimen Taguchi}

Berdasarkan pelaksanaan ekperimen yang dilakukan didapat hasil seperti yang tercantum pada tabel berikut.

Tabel 4.7. Data Hasil Percobaan Terhadap Kualitas Air

\begin{tabular}{cccccccccc}
\hline Eksperimen & 1 & 2 & 3 & 4 & 5 & 6 & 7 & Accept & Reject \\
\hline 1 & 1 & 1 & 1 & 1 & 1 & 1 & 1 & 2 & 2 \\
2 & 1 & 1 & 1 & 2 & 2 & 2 & 2 & 2 & 2 \\
3 & 1 & 2 & 2 & 1 & 1 & 2 & 2 & 2 & 2 \\
4 & 1 & 2 & 2 & 2 & 2 & 1 & 1 & 3 & 1 \\
5 & 2 & 1 & 2 & 1 & 2 & 1 & 2 & 2 & 2 \\
6 & 2 & 1 & 2 & 2 & 1 & 2 & 1 & 2 & 2 \\
7 & 2 & 2 & 1 & 1 & 2 & 2 & 1 & 3 & 1 \\
8 & 2 & 2 & 1 & 2 & 1 & 1 & 2 & 3 & 1 \\
\hline \multicolumn{2}{l}{ Berdasarkan } & hasil tersebut & di atas didapat & Persentase & Kesalahan pada Setiap
\end{tabular}

Eksperimen adalah sebagai berikut

Tabel 4.8. Persentase Kesalahan pada Setiap Eksperimen

\begin{tabular}{cccc}
\hline Ekperimen & Frekuensi Reject & $\begin{array}{c}\text { Persentase } \\
(\%)\end{array}$ & $\begin{array}{c}\text { Persentase Kumulatif } \\
(\%)\end{array}$ \\
\hline 1 & 2 & 15,38 & 15,38 \\
2 & 2 & 15,38 & 30,76 \\
3 & 2 & 15,38 & 46,14 \\
4 & 1 & 7,7 & 53,84 \\
5 & 2 & 15,38 & 69,22 \\
6 & 2 & 15,38 & 84,6 \\
7 & 1 & 7,7 & 92,3 \\
8 & 1 & 7,7 & 100 \\
\hline Total & 13 & 100 & \\
\hline
\end{tabular}




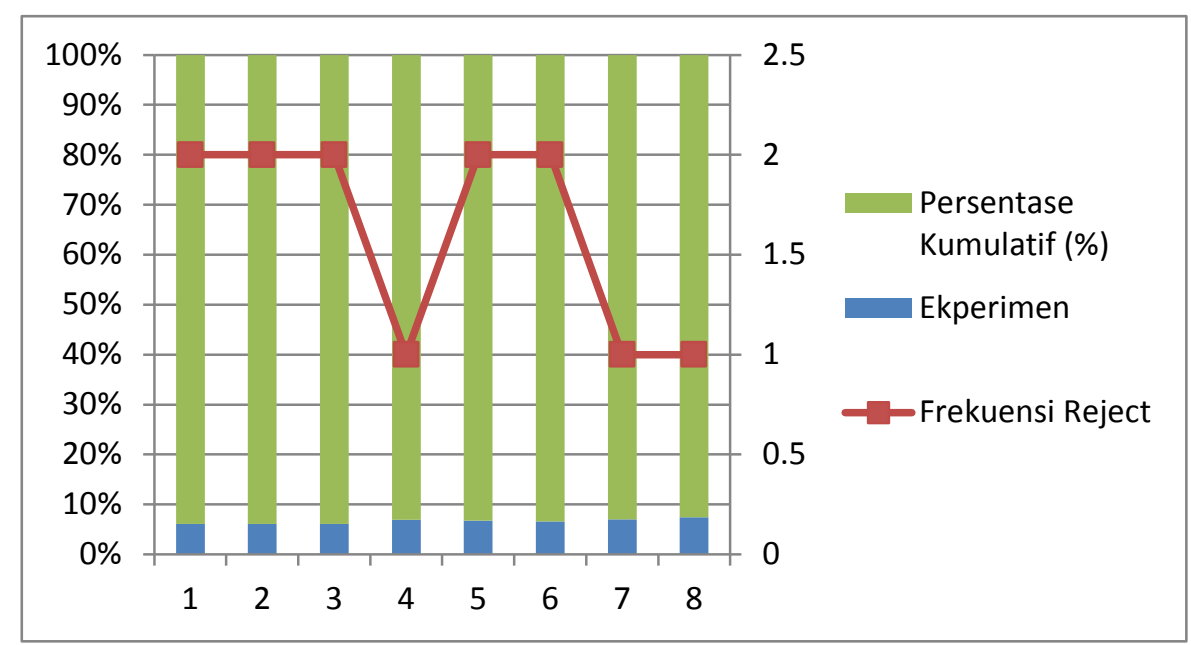

\subsection{Perhitungan Pengaruh Level dan Faktor.}

Berdasarkan perhitungan didapat respon rata-rata dari pengaruh faktor kualitas air dapat dilihat pada tabel 4.9.

Tabel 4.9. Tabel Respon Dari Pengaruh Faktor

\begin{tabular}{cccccccc}
\hline & $\mathrm{A}$ & $\mathrm{B}$ & $\mathrm{C}$ & $\mathrm{D}$ & $\mathrm{E}$ & $\mathrm{F}$ & $\mathrm{G}$ \\
\hline Level 1 & 1,75 & 2 & 1,5 & 1,75 & 1,75 & 1,5 & 1,5 \\
Level 2 & 1,5 & 1,25 & 1,75 & 1,5 & 1,5 & 1,75 & 1,75 \\
Selisih & 0,25 & 0,75 & 0,25 & 0,25 & 0,25 & 0,25 & 0,25 \\
Ranking & 7 & 1 & 2 & 3 & 4 & 5 & 6 \\
\hline
\end{tabular}

\subsection{Analisis Varians.}

Hasil perhitungan analisis varian seperti terdapat pada tabel berikut

Tabel 4.10 Analisis Varians

\begin{tabular}{ccccc}
\hline Faktor & V & SS & MS & F \\
\hline A & 1 & 0,125 & 0,125 & 1,005 \\
B & 1 & 1,125 & 1,125 & 1,053 \\
C & 1 & 0,125 & 0,125 & 1,005 \\
D & 1 & 0,125 & 0,125 & 1,005 \\
E & 1 & 0,125 & 0,125 & 1,005 \\
F & 1 & 0,125 & 0,125 & 1,005
\end{tabular}




\begin{tabular}{ccccc}
$\mathrm{G}$ & 1 & 0,125 & 0,125 & 1,005 \\
Error & $\mathbf{2 4}$ & $\mathbf{2 1 , 1 2 5}$ & $\mathbf{0 , 8 8}$ & $\mathbf{1}$ \\
$\mathbf{S}_{\mathbf{T}}$ & $\mathbf{3 1}$ & $\mathbf{3 2}$ & - & - \\
\hline
\end{tabular}

\subsection{Strategi Pooling $U p$}

Strategi pooling up dilakukan untuk menentukan faktor yang paling berpengaruh secara signifikan terhadap kualitas produk. Penentuan error dilakukan dengan mengumpulkan faktor-faktor yang tidak signifikan sebagai error. Pada pooling up dilakukan dengan ketentuan nilai $\mathrm{MS}_{\text {hitung }} \leq \mathrm{MS}_{\text {error }}$.

Tabel 4.11. Hasil Pooling

\begin{tabular}{ccccccc}
\hline Faktor & Pooled & V & SS & MS & F-ratio & SS' \\
\hline A & Y & 1 & 0,125 & 0,125 & - & - \\
B & - & 1 & 1,125 & 1,125 & 1,54 & 0,395 \\
C & Y & 1 & 0,125 & 0,125 & - & - \\
D & Y & 1 & 0,125 & 0,125 & - & - \\
E & $\mathrm{Y}$ & 1 & 0,125 & 0,125 & - & - \\
F & $\mathrm{Y}$ & 1 & 0,125 & 0,125 & - & - \\
G & $\mathrm{Y}$ & 1 & 0,125 & 0,125 & - & - \\
Error & - & 24 & 21,125 & 0,88 & 1 & - \\
Pooled & - & 30 & 21,875 & 0,73 & - & 31,605 \\
$\mathrm{~S}_{\mathrm{T}}$ & - & 31 & 32 & - & - & 32 \\
\hline
\end{tabular}

\subsection{Rasio $\mathrm{S} / \mathrm{N}$}

Karakteristik yang digunakan adalah smaller the better, maka $\mathrm{S} / \mathrm{N}$ ratio digunakan pada kategori reject. Nilai S/N ratio dapat dilihat pada tabel berikut.

Tabel 4.12. Nilai S/N Ratio

\begin{tabular}{cc}
\hline Eksperimen & S/N Ratio \\
\hline 1 & $-6,02$ \\
2 & $-6,02$ \\
3 & $-6,02$ \\
4 & 0 \\
5 & $-6,02$ \\
6 & $-6,02$ \\
7 & 0 \\
8 & 0 \\
\hline
\end{tabular}


Berdasarkan nilai rasion $\mathrm{S} / \mathrm{N}$ maka didapat peringkat nilai faktor seperti yang terdapat pada tabel berikut.

Tabel 4.13. Peringkat Faktor

\begin{tabular}{|c|c|c|c|c|}
\hline \multirow{2}{*}{ Faktor } & \multicolumn{2}{|c|}{ Level Faktor } & \multirow{2}{*}{ Selisih } & \multirow{2}{*}{ Ranking } \\
\hline & 1 & 2 & & \\
\hline A & $-4,515$ & $-3,01$ & 1,505 & 7 \\
\hline B & $-6,02$ & $-1,505$ & 4,515 & 1 \\
\hline $\mathrm{C}$ & $-3,01$ & $-4,515$ & 1,505 & 2 \\
\hline $\mathrm{D}$ & $-4,515$ & $-3,01$ & 1,505 & 3 \\
\hline $\mathrm{E}$ & $-4,515$ & $-3,01$ & 1,505 & 4 \\
\hline $\mathrm{F}$ & $-3,01$ & $-4,515$ & 1,505 & 5 \\
\hline $\mathrm{G}$ & $-3,01$ & $-4,515$ & 1,505 & 6 \\
\hline
\end{tabular}

\subsection{Pemilihan Kombinasi Level Faktor Optimal}

Berdasarkan hasil perhitungan maka pemilihan level faktor berdasarkan nilai level yang terkecil yaitu faktor B level 2. Sehingga setting kondisi aktual pada unit IPA Lapang berikut.

Tabel 4.15. Setting Kondisi Aktual IPA Lapang

\begin{tabular}{ccc}
\hline Faktor & Level & Satuan \\
\hline Air Baku (A) & Agak Keruh & - \\
Pembubuhan Aluminium Sulfate (B) & $1,0-2,5$ & Ppm \\
Pengadukan Cepat (C) & 110 & Rpm \\
Lama Waktu Pengadukan Cepat (D) & 60 & Detik \\
Pengadukan Lambat (E) & 30 & Rpm \\
Lama Waktu Pengadukan Lambat (F) & 20 & Menit \\
Pengendapan/Sedimentasi (G) & 20 & Menit \\
\hline
\end{tabular}

Sehingga berdasarkan tabel tersebut diperoleh setting percobaan terpilih seperti tercantum pada tabel berikut

Tabel 4.16. Setting Percobaan Terpilih

\begin{tabular}{ccc}
\hline Faktor & Level & Satuan \\
\hline Air Baku (A) & Agak Keruh & - \\
Pembubuhan Aluminium Sulfate (B) & $1,0-2,5$ & ppm \\
Pengadukan Cepat (C) & 100 & rpm \\
Lama Waktu Pengadukan Cepat (D) & 70 & Detik \\
Pengadukan Lambat (E) & 40 & rpm \\
Lama Waktu Pengadukan Lambat (F) & 15 & Menit \\
Pengendapan/Sedimentasi (G) & 20 & Menit \\
\hline
\end{tabular}




\subsection{Interpretasi Hasil Eksperimen}

Berdasarkan hasil perhitungan maka didapat persen kontribusi dapat dilihat pada tabel berikut

Tabel 4.16. Hasil Pooling

\begin{tabular}{cccccccc}
\hline Faktor & Pooled & V & SS & MS & F-ratio & SS & P (\%) \\
\hline A & Y & 1 & 0,125 & 0,125 & - & - & - \\
B & - & 1 & 1,125 & 1,125 & 1,54 & 0,395 & 1,23 \\
C & Y & 1 & 0,125 & 0,125 & - & - & - \\
D & Y & 1 & 0,125 & 0,125 & - & - & - \\
E & Y & 1 & 0,125 & 0,125 & - & - & - \\
F & Y & 1 & 0,125 & 0,125 & - & - & - \\
G & Y & 1 & 0,125 & 0,125 & - & - & - \\
Error & - & $\mathbf{2 4}$ & $\mathbf{2 1 , 1 2 5}$ & $\mathbf{0 , 8 8}$ & $\mathbf{1}$ & - & - \\
Pooled & - & $\mathbf{3 0}$ & $\mathbf{2 1 , 8 7 5}$ & $\mathbf{0 , 7 3}$ & - & $\mathbf{3 1 , 6 0 5}$ & - \\
S $_{\mathbf{T}}$ & - & $\mathbf{3 1}$ & $\mathbf{3 2}$ & - & - & $\mathbf{3 2}$ & - \\
\hline
\end{tabular}

\section{KESIMPULAN}

Berdasarkan hasil dan analisis yang dilakukan dalam penelitian ini dapat disimpulkan beberapa hal sebagai berikut: Penyebab kegagalan (reject) yang berpengaruh secara signifikan terhadap karakteristik kualitas air bersih adalah pembubuhan aluminium sulfhate (tawas), dengan persen kontribusi sebesar 1,23\%. Faktor-faktor yang penyebab terjadinya kecacatan terhadap kualitas air adalah air baku, pembubuhan tawas, pengadukan cepat, lama waktu pengadukan cepat, pengadukan lambat, lama waktu pengadukan lambat dan sedimentasi. Desain eksperimen solusi atau kombinasi setting yang optimal adalah $\mathrm{A}_{2}$ (air baku pada level agak keruh), $\mathrm{B}_{2}$ (pembubuhan tawas sebanyak 2,0-2,5 ppm per 1000 $\mathrm{ml}$ air), $\mathrm{C}_{1}$ (pengadukan cepat disetting $100 \mathrm{rpm}$ ), $\mathrm{D}_{2}$ (lama waktu pengadukan cepat diatur selama 70 detik), $\mathrm{E}_{2}$ (pengadukan lambat disetting $40 \mathrm{rpm}$ ), $\mathrm{F}_{1}$ (lama waktu pengadukan lambat diatur selama 15 menit) dan $\mathrm{G}_{1}$ (pengendapan/sedimentasi selama 20 menit). Hasil perhitungan yang dilakukan tanpa metode Taguchi, nilai ketidaksesuaian dengan standar mutu awal adalah 40,625\%. Sedangkan persentase ketidaksesuaian dengan standar mutu dengan metode Taguchi mengalami penurunan sebesar 9,375\% sehingga persentase ketidaksesuaian menjadi $31,25 \%$.

\section{DAFTAR PUSTAKA}

Amri. 2008. Analisis Pengendalian Kualitas Produk dengan Metode Taguchi. [Skripsi] Aceh Utara. Universitas Malikussaleh

Ariani, D.W. 1999. Manajemen Kualitas, Pendekatan Sisi Kualitatif. Depdiknas, Jakarta. 
Crosby. 2004. Manajemen Mutu Terpadu: M. Nur Nasution, 2004:41. Ghalia Indonesia, Jakarta.

Deming E. 2004. Manajemen Kualitas Produk \& Jasa: Drs Yamit Z, M.Si. Ekonosia, Yogyakarta.

Fingerbaum A.V. 1996. Kendali Mutu Terpadu. Erlangga, Jakarta.

Garvin D.A. 1996. Managing Quality. New York, Free Press.

Gasperz V, 2001. Metode Analisis Untuk Peningkatan Kualitas, PT. Gramedia Pustaka Utama, Jakarta.

Garvin dan Davis. 2004. Manajemen Mutu Terpadu: M. Nur Nasution, 2004:41. Ghalia Indonesia, Jakarta.

Ishak A. 2002. Rekayasa Kualitas. Universitas Sumatera Utara, 2: 1-24.

Montgomery D.C. 2001. Introduction to Statistical Quality Control. John Wiley \& Sons Inc., Singapore.

Musabbikah S dan Putro. 2002. Variansi Komposisi Bahan Genteng Soka Untuk Mendapatkan Daya Serap Air Yang Optimal. [Skripsi] Surakarta. Universitas Muhammadiyah Surakarta.

Nasution, M.N. 2004. Manajemen Mutu Terpadu. Ghalia Indonesia, Jakarta.

Prawirosentono S. 2004. Filosofi Baru Tentang Manajemen Mutu Terpadu, Total Quality Management Abad 21 Studi Kasus Dan Analisis Kiat Membangun Bisnis Kompetitif Bernuansa "Market Leader". Bumi Aksara, Jakarta.

Peraturan Menteri Kesehatan Republik Indonesia Nomor 492/MENKES/PER/IV/2010 Tentang Persyaratan Kualitas Air Minum.

Ross P.J. 1996. Taguchi Techniques for Quality Engineering, Second Edition. Mc Graw Hill Companies Inc. New York.

Soejanto I. 2009. Desain Eksperimen Dengan Metode Taguchi. Graha Ilmu. Yogyakarta.

Trisyulianti E dkk. 2003. Desain Sistem Pakar Untuk Interpretasi Bagan Kendali Mutu Pakan, Jurnal Teknik Industri Pertanian: 15(1): 17-27.

Wawolumaja R. 2009. Perbaikan Kualitas Dock Fender Menggunakan Metode Taguchi Parameter Design. [Skripsi] Bandung. Universitas Kristen Maranatha

Yamit Z Drs M.Si. 2004. Manajemen Kualitas Produk \& Jasa. Ekonosia, Yogyakarta. 